\title{
REKONSTRUKSI PENDIDIKAN ISLAM BERBASIS PEMBENTUKAN KARAKTER: Dari Konsep Menuju Internalisasi Nilai-Nilai Al-Qur'an
}

\author{
Asri Karolina \\ Sekolah Tinggi Agama Islam Negeri Curup, Bengkulu, Indonesia \\ asrikarolina@gmail.com
}

\begin{abstract}
This paper examines the reconstruction of Islamic education which is still facing various problems. The process of Islamic education is still focused and focused on the achievements cognitively. Implementation of Islamic education is still in the level of concept, not on internalization of the Qur'anic values which is the basic foundation of Islamic education. The problem of increasingly worrying is the rise of cases of moral decadence. This phenomenon seems to re-question the role of Islamic education in shaping the character of learners. Therefore, it is necessary to reconstruct Islamic education based on character formation with the concept of internalization of Al-Qur'an values. The results of this paper explain that there are 3 things that can be done in reconstructing Islamic education-based character formation with the concept of internalization of Al-Qur'an values are: first, educators must first do personal recognition with learners. Secondly, all parties involved in educational institutions should present themselves as role models for
\end{abstract}


learners. third, to apply character education based on Al-Qur'an with 4 stages of learning experience, reflection, action, and evaluation.

Keywords: Islamic Education, Character Building, AlQur'an Values

\begin{abstract}
Abstrak
Tulisan ini mengkaji tentang rekonstruksi pendidikan Islam yang sampai saat ini masih menghadapi berbagai masalah. Proses pendidikan Islam masih menitikberatkan dan memfokuskan pada capaian secara kognitif. Pelaksanaan pendidikan Islam masib dalam tataran konsep, belum pada internalisasi nilai-nilai Al-Qur'an yang merupakan dasar pokok pendidikan Islam. Persoalan yang semakin mengkhawatirkan adalah mencuatnya kasus dekadensi akhlak. Berbagai peristiwa yang merendabkan harkat dan martabat manusia berkembang di masyarakat bahkan dalam dunia pendidikan yang dilakukan oleh peserta didik, seperti hancurnya nilai-nilai keislaman, merebaknya kasus bullying, dan meningkatnya kasus amoral. Fenomena ini seolah mempertanyakan kembali peranan pendidikan Islam dalam membentuk karakter peserta didik. Untuk itu, perlu adanya rekonstruksi pendidikan Islam berbasis pembentukean karakter dengan konsep internalisasi nilai-nilai Al-Qur'an. Hasil tulisan ini menjelaskan babwa ada 3 hal yang bisa dilakukan dalam merekonstruksi pendidikan Islam berbasis pembentukan karakter dengan konsep internalisasi nilai-nilai Al-Qur'an yaitu: pertama, pendidik harus terlebih dabulu melakukan pengenalan pribadi dengan peserta didik. kedua, semua pihak yang terlibat di dalam lembaga pendidikan harus menampilkan diri sebagai suri tauladan bagi peserta didik. ketiga, menerapkan pendidikan karakter berbasis Al-Qur'an dengan 4 tahapan yaitu pengalaman pembelajaran, refleksi, aksi, dan evaluasi.
\end{abstract}

Kata Kunci: Pendidikan Islam, Pembentukan Karakter, NilaiNilai Al-Qur'an

\title{
A. Pendahuluan
}

Keberhasilan suatu bangsa dalam memperoleh tujuannya tidak hanya ditentukan oleh melimpah ruahnya sumber daya alam, 
tetapi sangat ditentukan oleh kualitas sumber daya manusianya. Bahkan ada yang mengatakan bahwa "Bangsa yang besar dapat dilihat dari kualitas/karakter bangsa (manusia) itu sendiri. ${ }^{1}$

Diakui atau tidak bahwa karakter generasi muda akhirakhir ini banyak mengalami kelunturan yang sangat dahsyat. Generasi muda sekarang, baik di desa maupun di kota banyak menghabiskan waktunya hanya untuk bermain playstation, gadget, game online, dan sejenisnya, mereka hampa akan nilai-nilai budaya lokal serta asing terhadap istilah-istilah seperti budi pekerti, tata krama, gotong royong dan nilai-nilai luhur lainnya yang ada di bumi nusantara ini. Berbagai aktivitas kehidupan dan permainan seakan-akan membuatnya sibuk bahkan sudah tidak mengenal lagi arti pentingnya interaksi sosial dan kerjasama, ditambah lagi dengan kondisi sekolah akhir-akhir ini yang banyak menyita waktu, sehingga semakin membatasi anak-anak untuk mempelajari berbagai kearifan lokal. Tentunya hal ini merupakan kegagalan pendidikan dalam menyikapi perubahan zaman yang tidak berpihak pada pembentukan karakter yang berbasiskan agama dan moralitas. Memang, anak-anak merupakan masa penting bagi pertumbuhan dan penanaman nilai-nilai moral bangsa, karena masa itu merupakan masa emas untuk melukiskan nilainilai karakter bijak dalam benak sanubarinya. Anak yang dibekali dengan akhlak dan pengalaman hidup dengan baik, ia akan tumbuh menjadi anak yang berbudi, bernilai, kreatif, dan mandiri. Sebaliknya jika anak itu selalu disuguhi dengan kesibukan yang tidak jelas, permainan yang melalaikan, serta berbagai tontonan yang tidak bermutu, maka bisa dipastikan ia akan cenderung berperilaku tidak sesuai dengan karakter bangsa. Hal ini tentu akan merugikan terhadap dirinya sendiri juga lingkungan sekitar. Maka diperlukan sebuah solusi untuk menjadikan generasi muda

${ }^{1}$ Abdul Majid dan Dian Andayani, Pendidikan Karakter Perspektif Islam, (Bandung: PT. Remaja Rosdakarya, 2012), hlm. 2. 


\section{Asri Karolina}

ini agar menjadi generasi yang berkarakter kuat, unggul, beriman dan beradab. ${ }^{2}$

Pandangan simplistik menganggap, bahwa kemerosotan akhlak, moral, dan etika peserta didik disebabkan gagalnya pendidikan agama di sekolah. Harus diakui, dalam batas tertentu, pendidikan agama memiliki kelemahan-kelemahan tertentu, sejak dari jumlah jam yang minim, materi pendidikan agama yang terlalu banyak teoritis, sampai kepada pendekatan pendidikan agama yang cenderung bertumpu pada aspek kognisi daripada afeksi dan psikomotorik peserta didik. Berhadapan dengan berbagai kendala, constraints, dan masalah-masalah seperti ini, pendidikan agama tidak atau kurang fungsional dalam membentuk akhlak, moral, dan bahkan kepribadian peserta didik. ${ }^{3}$

Sejauh menyangkut krisis mentalitas dan moral peserta didik, terdapat beberapa masalah pokok yang turut menjadi akar krisis mentalitas dan moral di lingkungan pendidikan nasional: a) arah pendidikan telah kehilangan objektivitasnya. Sekolah dan lingkungannya tidak lagi merupakan tempat peserta didik melatih diri untuk berbuat sesuatu berdasarkan nilai-nilai moral dan akhlak. b) proses pendewasaaan diri tidak berlangsung baik di lingkungan sekolah. c) proses pendidikan di sekolah sangat membelenggu peserta didik dan bahkan juga para guru. d) beban kurikulum yang demikian berat, lebih parah lagi, hampir seluruhnya diorientasikan pada pengembangan ranah kognitif belaka. e) kalaupun ada materi yang dapat menumbuhkan rasa afeksi seperti mata pelajaran agama misalnya, umumnya disampaikan dalam bentuk verbalisme. f) pada saat yang sama para peserta didik dihadapkan dengan nilai-nilai yang sering bertentangan (contra-dictory set of values). Pada satu pihak mereka

${ }^{2}$ Muthoifin dan Mutohharun Jinan, "Pendidikan Karakter Ki Hadjar Dewantara: Studi Kritis Pemikiran Karakter dan Budi Pekerti dalam Tinjauan Islam”, Jurnal Profetika, Jurnal Studi Islam, Volume 16, No. 2, Desember 2015, hlm. 167-168.

${ }^{3}$ Muthoifin dan Mutohharun Jinan, "Pendidikan Karakter Ki Hadjar Dewantara...", hlm. 168. 
diajar para guru pendidikan agamanya untuk bertingkah laku baik seperti: jujur, hemat, rajin, disiplin dan sebagainya, tetapi pada saat yang sama, banyak orang di lingkungan sekolah justru melakukan tindakan berlawanan dengan hal-hal seperti itu. g) selain itu para peserta didik juga mengalami kesulitan dalam mencari figur panutan untuk dijadikan sebagai teladan (uswah hasanab) di lingkungan sekolah maupun di lingkungan masyarakat. ${ }^{4}$

Jadi dapat dipahami bahwa pendidikan Islam saat ini masih menghadapi berbagai masalah. Capaian hasil pendidikan masih belum memenuhi tujuan pendidikan Islam yang diharapkan. Pembelajaran di kelas juga belum mampu membentuk pribadi lulusan yang mencerminkan karakter muslim yang bernilai. Proses pendidikan Islam masih menitikberatkan dan memfokuskan pada capaian secara kognitif belum pada aspek afektif yang merupakan bekal kuat untuk hidup berdampingan dengan masyarakat dan dapat menjadi agent of change bagi lingkungan masyarakat yang sedang menghadapi kemerosotan karakter/akhlak.

Menyikapi fenomena tersebut, dunia pendidikan harus memberi peran penting dalam menangkal dekadensi moral bangsa, dalam upaya menyiapkan generasi muda masa depan yang lebih baik. Dalam sistem pendidikan nasional, Undang-Undang telah mengamanatkan agar tujuan pendidikan diarahkan agar peserta didik menjadi manusia beriman dan bertakwa, memiliki akhlak mulia, sehat lahir maupun bathin, berilmu, memiliki kecakapan dan kreatifitas, memiliki kemandirian, menjadi warga Negara yang demokratis dan memiliki sikap yang bertanggung jawab. ${ }^{5}$ Para cendikiawan telah menawarkan berbagai wacana baru tentang model dan muatan pendidikan. Hal ini merupakan upaya untuk menemukan solusi dalam membangun peradaban bangsa. Pada tahun 2008 yang diprakarsai oleh Universitas Paramadina Jakarta, lewat sebuah gerakan 'memasyarakatkan pendidikan integritas'

\footnotetext{
${ }^{4}$ Ibid, hlm. 168-169.

${ }^{5}$ Undang-Undang Republik Indonesia Nomor 20 Tahun 2003 tentang Sistem Pendidikan Nasional.
} 


\section{Asri Karolina}

di tanah air melalui lembaga TIRI. Lembaga ini mencoba menyerukan pentingnya pendidikan integritas dan pembentukan karakter bagi elemen bangsa yang sedang dilanda wabah KKN (Korupsi, Kolusi, dan Nepotisme). Selanjutnya, pada tahun 2010, Kementerian Pendidikan Nasional melalui peringatan Hari Pendidikan Nasional mulai menggagas pentingnya pendidikan karakter untuk menjawab permasalahan moral dalam dunia pendidikan di Indonesia, dengan mengangkat tema "Pendidikan Karakter untuk Membangun Peradaban Bangsa".

Berbicara soal karakter, maka perlu disimak apa yang ada dalam UU Nomor 20 Tahun 2003 tentang Sistem Pendidikan Nasional pada pasal 3, yang menyebutkan: "Pendidikan nasional berfungsi mengembangkan kemampuan dan membentuk karakter serta peradaban bangsa yang bermartabat dalam rangka mencerdaskan kehidupan bangsa,..." dalam UU ini secara jelas ada kata "karakter". Kendati tidak ada penjelasan lebih lanjut tentang apa yang dimaksudkan dengan karakter, sehingga menimbulkan berbagai tafsir dengan maksud kata tersebut. Ada berbagai pendapat tentang apa itu karakter atau watak. Watak atau karakter berasal dari kata Yunani "charassein", yang berarti barang atau alat untuk menggores, yang di kemudian hari dipahami sebagai stempel/cap. Jadi, watak itu sebuah stempel atau cap, sifat-sifat yang melekat pada seseorang. Watak sebagai sifat seseorang dapat dibentuk, artinya watak seseorang dapat berubah, kendati watak mengandung unsur bawaan (potensi internal), yang setiap orang dapat berbeda. Namun, watak amat dipengaruhi oleh faktor eksternal, yaitu keluarga, sekolah, masyarakat, lingkungan pergaulan, dan lain-lain. ${ }^{7}$

${ }^{6}$ Amri Rahman \& Dulsukmi Kasim, "Pendidikan Karakter Berbasis AlQur'an; Upaya Menciptakan Bangsa yang Berkarakter”, Jurnal Al-Ulum IAIN Sultan Amai Gorontalo, Volume 14 Nomor 1, Juni 2014, hlm. 248-249.

${ }^{7}$ Sutarjo Adisusilo, J.R., Pembelajaran Nilai Karakter: Konstruktivisme dan VCT sebagai Inovasi Pendekatan Pembelajaran Afektif, (Jakarta: PT. Rajawali Pers, 2013), hlm. 76-77. 
Istilah "watak" itu terkandung makna adanya sifatsifat baik yang melekat pada diri seseorang sehingga tercermin dalam pola pikir dan pola tingkah lakunya. Watak seseorang dapat dibentuk, dapat dikembangkan dengan pendidikan nilai. Pendidikan nilai akan membawa pada proses internalisasi nilai, dan proses internalisasi nilai akan mendorong seseorang untuk mewujudkannya dalam tingkah laku, dan akhirnya pengulangan tingkah laku yang sama akan menghasilkan watak seseorang. Watak atau karakter itu amat penting, dapat disimak dari hasil penelitian di Harvard University Amerika Serikat yang memaparkan bahwa kesuksesan hidup seseorang tidak ditentukan semata-mata oleh pengetahuan dan kemampuan teknis (hard skill) yang diperoleh lewat pendidikan, tetapi lebih oleh kemampuan mengelola diri yang di dalamnya termasuk karakter dan orang lain (soft skill). Penelitian ini mengungkapkan, bahwa kesuksesan seseorang hanya ditentukan sekitar $20 \%$ oleh hard skill dan sisanya $80 \%$ oleh soft skill. Bahkan orang-orang tersukses di dunia bisa berhasil dikarenakan lebih banyak didukung kemampuan soft skill daripada hard skill. Hal ini mengisyaratkan bahwa pendidikan karakter peserta didik sangat penting untuk dikembangkan. ${ }^{8}$

Pendidikan karakter merupakan bagian dari pendidikan nilai (values education) yang ditanamkan sejak bangku sekolah. Sebab ke depan, sekolah tidak hanya bertanggung jawab dalam mencetak peserta didik yang unggul dalam ilmu penggetahuan dan teknologi tetapi juga memiliki pribadi yang berkarakter dan berkepribadian sebagaimana dituntut dalam tujuan pendidikan nasional. Sebagai bangsa yang penduduknya mayoritas beragama Islam, tentu tidak salah jika menjadikan kitab suci umat AlQur'an sebagai inspirasi dalam membangun karakter bangsa. Sebagai kitab suci, Al-Qur'an sarat dengan konsep dan nilai-nilai moral yang sangat relevan untuk dijadikan sebagai rujukan utama dalam pembinaan karakter masarakat, khususnya generasi muda. Hal ini sangat beralasan, sebab Al-Qur'an telah terbukti berhasil

${ }^{8}$ Sutarjo Adisusilo, J.R., Pembelajaran Nilai Karakter..., hlm. 79. 
dalam merubah karakter bangsa Arab yang sebelumnya diwarnai dengan berbagai macam bentuk penyimpangan. Sejak hadirnya Al-Qur'an di tengah-tengah masyarakat Arab, terjadi suatu transformasi budaya dari masyarakat jahiliyah menuju masyarakat yang berperadaban. ${ }^{9}$

Fenomena ini seolah mempertanyakan kembali peranan pendidikan Islam dalam membentuk karakter peserta didik. Untuk itu, perlu adanya rekonstruksi pendidikan Islam berbasis pembentukkan karakter dengan konsep internalisasi nilai-nilai Al-Qur'an yang seejatinya merupakan dasar pokok pendidikan Islam.

\section{B. Pembahasan}

\section{Pendidikan Islam}

Pendidikan pada hakikatnya adalah proses pembinaan akal manusia yang merupakan potensi utama dari manusia sebagai makhluk berpikir. Dengan pembinaan olah pikir, manusia diharapkan semakin meningkat kecerdasannya dan meningkat pula kedewasaan berpikirnya, terutama memiliki kecerdasan memecahkan permasalahan dalam kehidupannya. Pendidikan pada hakikatnya juga merupakan pelatihan keterampilan setelah manusia memperoleh ilmu pengetahuan yang memadai dari hasil olah pikirnya. Keterampilan yang dimaksudkan adalah suatu objek tertentu yang meembantu kehidupan manusia karena dengan keterampilan tersebut, manusia mencari rezeki dan mempertahankan kehidupannya. Pendidikan Islam dapat diartikan secara praktis sebagai hakikat pengajaran Al-Qur'an dan As-Sunnah. Berdasarkan firman Allah SWT. dalam surat AsySyura ayat 52 sebagai berikut: ${ }^{10}$

${ }^{9}$ Amri Rahman \& Dulsukmi Kasim, "Pendidikan Karakter Berbasis AlQur'an...”, hlm. 249.

${ }^{10}$ Hasan Basri, Filsafat Pendidikan Islam, (Bandung: Pustaka Setia, 2009), hlm. 56-57. 


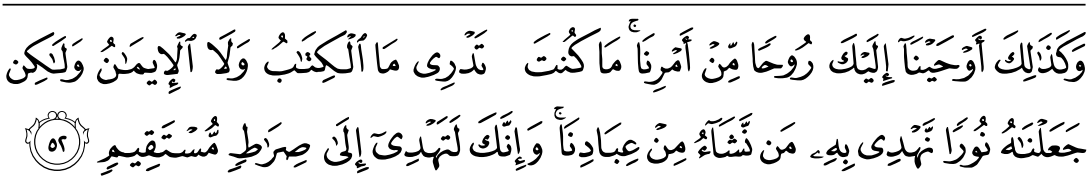

"Dan demikianlah Kami wabyukan kepadamu wabyu (Al-Qur'an) dengan perintah kami. sebelumnya kamu tidaklah mengetahui Apakah Al kitab (Al-Qur'an) dan tidak pula mengetahui Apakah iman itu, tetapi Kami menjadikan Al-Qur'an itu cabaya, yang Kami tunjuki dengan Dia siapa yang Kami kehendaki di antara hamba-hamba kami. dan Sesungguhnya kamu benar-benar memberi petunjuk kepada jalan yang lurus (Q.S. Asy-Syura: 52).

Ayat tersebut menjelaskan bahwa Al-Qur'an adalah cahaya yang memberi petunjuk kehidupan. Dengan demikian, hakikat pendidikan Islam adalah upaya tanpa putus asa untuk menggali hidayah yang terkandung dalam Al-Qur'an. Hidayah yang dimaksudkan adalah hidayah iman, hidayah ilmu, dan hidayah amal. Hidayah iman artinya semua orang yang menggali kandungan Al-Qur'an hendaknya beriman kepada Allah dan Rasulullah SAW. serta beriman kepada kitab Al-Qur'an. Hidayah ilmu artinya penggalian terhadap ayat-ayat Al-Qur'an yang memberi informasi dan idea dasar semua ilmu pengetahuan manusia, sedangkan hidayah amal artinya kita diberi kekuatan fisik dan mental untuk mengamalkan seluruh ilmu yang yang telah digali dalam Al-Qur'an.

Sedangkan pendidikan Islam yaitu bimbingan secara sadar dan pendidik (orang dewasa) kepada anak yang masih dalam proses pertumbuhannya berdasarkan norma-norma yang Islami agar berbentuk kepribadiannya menjadi kepribadian muslim. ${ }^{11}$ Pendidikan Islam juga diartikan sebagai usaha orang dewasa muslim yang bertakwa secara sadar mengarahkan dan membimbing pertumbuhan serta perkembangan fitrah

${ }^{11}$ Nur Uhbiyati, Dasar-Dasar Imu Pendidikan Islam, (Semarang: Pustaka Rizki Putra, 2013), hlm. 163. 
(kemampuan dasar) anak didik melalui ajaran Islam ke arah titik maksimal pertumbuhan dan perkembangannya. ${ }^{12}$

Jadi, dapat dipahami bahwa pendidikan Islam merupakan usaha sadar membina dan membimbing peserta didik dalam memahami ajaran Islam secara menyeluruh. Pendidik secara sadar mengarahkan pada pembentukan karakter peserta didik menjadi kepribadian muslim dan muslimah berdasarkan norma-norma Islam yang terkandung dalam Al-Qur'an dan hadis.

H.M, Arifin mengemukakan bahwa tujuan pendidikan Islam adalah "membina dan mendasari kehidupan anak dengan nilai-nilai syariat Islam secara benar sesuai dengan pengetahuan agama". Sedangkan Imam al-Ghazali berpendapat bahwa tujuan pendidikan Islam yang paling utama adalah "beribadah dan bertaqarrub kepada Allah, dan kesempurnaan insan yang tujuannya kebahagiaan dunia dan akhirat". Selanjutnya Ahmad D. Marimba menyatakan bahwa tujuan pendidikan Islam adalah "untuk membentuk kepribadian yang Muslim, yakni bertakwa kepada Allah". Pendapat tersebut sesuai dengan firman Allah yang artinya dalam Al-Qur'an surat Adz-Dzariyat ayat 56 berikut ini: $:^{13}$

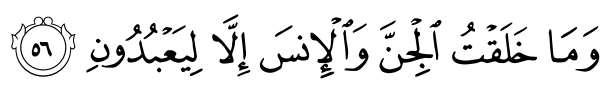

"dan aku tidak menciptakan jin dan manusia melainkan supaya mereka mengabdi kepada-Ku” (Q.S. Adz-Dzariyat: 56).

Di samping itu, Zakiah Daradjat mengemukakan bahwa tujuan pendidikan Islam adalah "untuk membentuk manusia yang beriman dan bertakwa kepada Allah Swt. selama hidupnya, dan matipun tetap dalam keadaan Muslim". Pendapat ini didasari firman Allah Swt. dalam surat Ali Imran ayat 102 sebagai berikut:

${ }^{12}$ H.M. Arifin, Ilmu Pendidikan Islam: Tinjauan Teoretis dan Praktis Berdasa kan Pendekatan Interdisipliner, Edisi Revisi, (Jakarta: Bumi Aksara, 2011), hlm. 22.

${ }^{13}$ Akmal Hawi, Kapita Selekta Pendidikan Islam, (Palembang: IAIN Raden Fatah Press, 2008), hlm. 20. 
"Hai orang-orang yang beriman, bertakwalah kepada Allah sebenarbenar takwa kepada-Nya; dan janganlah sekali-kali kamu mati melainkan dalam Keadaan beragama Islam" (Q.S. Ali Imran: 102).

Terdapat tiga nilai utama dalam Islam, yaitu akhlak, adab dan keteladanan. Akhlak merujuk kepada tugas dan tanggung jawab selain syar" ab dan ajaran Islam secara umum. Sedangkan adab merujuk kepada sikap yang dihubungkan dengan tingkah laku yang baik. Dan keteladanan merujuk kepada kualitas karakter yang ditampilkan oleh seorang muslim yang baik yang mengikuti keteladanan Nabi Muhammad SAW. Ketiga nilai inilah yang menjadi pilar karakter dalam Islam. Nilai-nilai agama dan nilainilai demokrasi bukanlah hal yang dipertentangkan hari ini. Jika dipahami lebih utuh dan integral, nilai-nilai ini dapat memberikan sumbangan yang efektif bagi sebuah penciptaan masyarakat yang stabil dan mampu berkerjasama dalam mencapai tujuan bersama. Ini sesungguhnya menjadi semangat dalam pasal-pasal pancasila. Oleh karena itu pendidikan agama merupakan dukungan dasar yang tak tergantikan bagi keutuhan pendidikan karakter, karena dalam agama terkandung nilai-nilai luhur yang mutlak kebaikan dan kebenaranya. Berdasarkan kajian berbagai nilai agama, norma sosial, peraturan atau hukum, etika akademik, dan prinsip-prinsip HAM, telah teridentifikasi butir-butir nilai yang dikelompokan menjadi lima nilai utama, yaitu nilai-nilai perilaku manusia dalam hubungannya dengan Tuhan Yang Maha Esa, diri sendiri, sesama manusia, lingkungan dan kebangsaan. ${ }^{14}$

Maka pendidikan karakter memiliki tujuan yang sama dengan tujuan pendidikan Islam, Menurut Al-Attas "pendidikan dalam arti Islam adalah sesuatu yang khusus hanya untuk manusia" pernyataan ini mengindikasikan bahwa pendidikan

${ }^{14}$ Hermawansyah, "Pendidikan Karakter Berbasis Nilai-Nilai Islam”, Ju nal Ilmiah "Kreatif” Jurnal Studi Pemikiran Pendidikan Agama Islam, Volume XII No. 1, Januari 2015, hlm. 9-10. 


\section{Asri Karolina}

Islam secara filosofis seyogyanya memiliki konsepsi yang jelas dan tegas mengenai manusia. Dengan demikian kalau pendidikan dalam Islam hanya untuk manusia, manusia yang bagaimana yang dikehendaki pendidikan Islam?. Munurut M. Arifin, pendidikan Islam yang bermaksud membentuk manusia yang perilakunya didasari dan dijiwai dari Iman dan takwa kepada Allah, yaitu manusia yang dapat "merealisasikan identitas Islami" yang menghambakan sepenuhnya kepada Allah. Maka dari ini semua Natsir menyimpulkan bahwa pendidikan Islam sebenarnya bermaksud merealisasikan tujuan hidup Muslim itu sendiri, yaitu penghambaan sepenuhnya kepada Allah. Hal ini sesuai dengan maksud firman Allah dalam Q.S. Adz-Dzariyat: $56 .{ }^{15}$

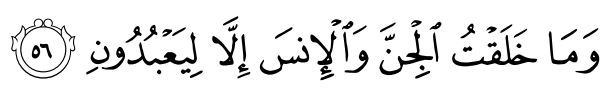

"Dan aku tidak menciptakan jin dan manusia melainkan supaya mereka mengabdi kepada-Ku” (Q.S. Adz-Dzariyat: 56).

Hingga saat ini masih ditengarai bahwa sistem pendidikan Islam belum mampu menghadapi perubahan dan menjadi counter ideas terhadap globalisasi kebudayaan. Oleh sebab itu, pola pengajaran maintenance learning yang selama ini dipandang terlalu bersifat adaptif dan pasif harus segera ditinggalkan. Dengan begitu, maka lembaga pendidikan Islam setiap saat dituntut untuk selalu melakukan rekonstruksi pemikiran pendidikan dalam rangka mengantisipasi setiap perubahan yang terjadi. Setidaknya ada tiga faktor yang menjadikan model

pendidikan Islam berwatak statis dan tertinggal: pertama, subject matter pendidikan Islam masih berorientasi ke masa lalu dan bersifat normatif serta tekstual. Ini bukan berarti bahwa kita harus meninggalkan warisan masa lalu. Warisan masa lalu sangat berharga nilainya karena ia merupakan mata rantai sejarah yang tidak boleh diabaikan. Prinsip: "tetap memelihara tradisi warisan masa lalu yang baik dan mengambil tradisi yang lebih baik"

${ }^{15}$ Hermawansyah, "Pendidikan Karakter Berbasis Nilai-Nilai Islam"..., hlm. 10-11. 
(almuhafadhat ala al-qadîm al-shalih wa al-akhdzu bi al-jadîd al-ashlab), justru merupakan prinsip yang tepat bagi sebuah rekonstruksi pemikiran pendidikan Islam; kedua, masih

mengentalnya sistem pengajaran maintenance learning yang bercirikan lamban, pasif, dan menganggap selalu benar terhadap warisan masa lalu; ketiga, masih ada pandangan dikotomis ilmu secara subtansial (ilmu agama dan ilmu umum). Dalam upaya merekonstruksi pendidikan Islam, kita perlu memperhatikan prinsip-prinsip pendidikan Islam yang meliputi: pertama, pendidikan Islam merupakan bagian dari sistem kehidupan Islam, yaitu suatu proses internalisasi dan sosialisasi nilai-nilai moral Islam melalui sejumlah informasi, pengetahuan, sikap perilaku, dan budaya; kedua, pendidikan Islam merupakan sesuatu yang integrated artinya mempunyai kaitan yang membentuk suatu kesatuan yang integral dengan ilmu-ilmu yang lain; ketiga, pendidikan Islam merupakan life long process sejak dini kehidupan manusia, keempat, pendidikan Islam berlangsung melalui suatu proses yang dinamis, yakni harus mampu menciptakan iklim dialogis dan interaktif antara pendidik dan peserta didik, kelima, pendidikan Islam dilakukan dengan memberi lebih banyak mengenai pesan-pesan moral pada peserta didik. ${ }^{16}$

Akhir-akhir ini, dunia pendidikan disuguhkan formula yang disebut "pendidikan karakter" suatu bentuk pendidikan yang tidak hanya menekankan tingginya IQ peserta didik tetapi juga mampu menerapkannya secara nyata dalam kehidupan atas apa yang dipahaminya benar menurut nilai-nilai agama, moral, dan budaya. Nilai-nilai agama dapat diajarkan lewat pendidikan Islam. Untuk itu, penting untuk mengkaji pendidikan karakter perspektif pendidikan Islam guna menguji kemampuan pendidikan karakter dalam mengembalikan citra positif dunia pendidikan. ${ }^{17}$

${ }^{16}$ Rakhmawati, "Pendidikan Karakter dalam Perspektif Islam", Jurnal Al-Ulum (Jurnal Studi-Studi Islam) IAIN Gorontalo, Volume 13 Nomor 1, Juni 2013, hlm. 193-194.

${ }^{17}$ Rakhmawati, "Pendidikan Karakter dalam Perspektif Islam"..., hlm. 194. 
Pendidikan karakter diyakini mampu menyelesaikan permasalahan pendidikan Islam yang diduga belum mampu mencapai tujuan pendidikan Islam secara menyeluruh. Sehingga kita dapat memformulasikan pendidikan Islam berbasis pembentukan karakter yang sebenarnya tujuan pembentukan karakter dan pendidikan Islam memiliki orientasi yang sama.

\section{Pendidikan Karakter}

Membicarakan karakter merupakan hal yang sangat penting dan mendasar. Karakter adalah mustika hidup yang membedakan manusia dengan binatang. Manusia tanpa karakter adalah manusia yang sudah "membinatang". Orang-orang yang berkarakter kuat dan baik secara individual maupun sosial ialah mereka yang memiliki akhlak, moral, dan budi pekerti yang baik. Mengingat begitu urgennya karakter, maka institusi pendidikan memiliki tanggung jawab untuk menanamkannya melalui proses pembelajaran. ${ }^{18}$

Penguatan pendidikan karakter dalam konteks sekarang sangat relevan untuk mengatasi krisis moral yang sedang terjadi di negara kita. Diakui atau tidak diakui saat ini terjadi krisis yang nyata dan mengkhawatirkan dalam masyarakat dengan melibatkan milik kita yang paling berharga, yaitu anak-anak. Krisis itu antara lain berupa meningkatnya pergaulan seks bebas, maraknya angka kekerasan anak-anak dan remaja ${ }^{19}$, kejahatan tehadap teman, pencurian remaja, kebiasaan menyontek, dan penyalahgunaan

${ }^{18}$ Zubaedi, Desain Pendidikan Karakter: Konsepsi dan Aplikasinya dalam Le baga Pendidikan, (Jakarta: Kencana Prenada Media Group, 2011), hlm. 1.

${ }^{19}$ Kekerasan yang dilakukan pelajar kian memprihatinkan, seperti aksi premanisme yang dilakukan oleh pelajar yang tergabung dalam Geng Nero (neko-neko dikeroyok), dan banyak lagi perilaku kekerasan lainnya. Geng Nero barangkali hanya salah satu potret dari sekian banyak geng yang ada di lingkungan masyarakat yang dilakukan oleh pelajar. Kejadian ini mungkin juga pernah dialami oleh sekolah-sekolah lain, namun tidak terekspos media massa. Baca Dimyati, "Peran Guru sebagai Model dalam Pembelajaran Karakter dan Kebajikan Moral Melalui Pendidikan Jasmani”, dalam Cakerawala Pendidikan, (Yogyakarta, UNY, Mei 2010, Th. XXIX, Edisi Khusus Dies Natalis UNY), hlm. 8 
obat-obatan, pornografi, perkosaan, perampasan, dan perusakan milik orang lain sudah menjadi masalah sosial yang hingga saat ini belum dapat diatasi secara tuntas. Perilaku rmaja kita juga diwarnai dengan gemar menyontek, kebiasaan bullying di sekolah, dan tawuran. Akibat yang ditimbulkan cukup serius dan tidak dapat lagi dianggap sebagai suatu persoalan sederhana karena tindakan ini telah menjurus kepada tindakan kriminal. Perilaku orang dewasa juga setali tiga uang, senang dengan konflik dan kekerasan atau tawuran, perilaku korupsi yang merajalela, dan perselingkuhan. $^{20}$

Kondisi krisis ${ }^{21}$ dan dekadensi moral ini menandakan bahwa seluruh pengetahuan agama dan moral yang didapatkannya di bangku sekolah ternyata tidak berdampak terhadap perubahan perilaku manusia Indonesia. Bahkan yang terlihat adalah begitu banyaknya manusia Indonesia yang tidak konsisten, lain yang dibicarakan, dan lain pula tindakannya. Banyak orang berpandangan bahwa kondisi demikian diduga berawal dari apa yang dihasilkan oleh dunia pendidikan. Demoralisasi terjadi karena proses pembelajaran cenderung mengajarkan pendidikan moral dan budi pekerti sebatas teks dan kurang mempersiapkan siswa untuk menyikapi dan menghadapi kehidupan yang kontadiktif. Pendidikanlah yang sesungguhnya paling besar memberikan kontribusi terhadap situasi ini. Dalam konteks pendidikan formal di sekolah, bisa jadi salah satu penyebabnya karena pendidikan di Indonesia lebih menitikberatkan pada pengembangan intelektual atau kognitif semata, sdangkan aspek soft skills atau nonakademik sebagai unsur utama pendidikan kakrakter belum diperhatikan secara optimal bahkan cenderung diabaikan. Saat ini, ada kecenderungan bahwa target-target akademik masih menjadi tujuan utama dari hasil pendidikan, seperti halnya Ujian

${ }^{20}$ Zubaedi, Desain Pendidikan Karakter..., hlm. 1-2.

${ }^{21}$ Menurut tinjauan ESQ, tujuh krisis moral yang terjadi di tengah-te gah masyarakat Indonesia antara lain krisis kejujuran, krisis tanggung jawab, tidak berpikir jauh ke depan, krisis disiplin, krisis kebersamaan, dan krisis keadilan. Baca Darmiyati Zuhdi, Pendidikan Karakter, (Yogyakarta: UNY, 2009), hlm. 39-40. 
Nasional (UN), sehingga proses pendidikan karakter masih sulit dilakukan. $^{22}$

Suprapto menjelaskan bahwa pendidikan karakter memiliki makna lebih tinggi daripada pendidikan moral karena bukan sekedar mengajarkan mana yang benar dan mana yang salah. Lebih dari itu, pendidikan karakter menanamkan kebiasaan (babituation) tentang yang baik sehingga siswa didik menjadi paham, mampu merasakan, dan mau melakukan hal yang baik. Menurut Megawati, pembedaan ini karena moral dan karakter adalah dua hal yang berbeda. Moral adalah pengetahuan seseorang terhadap hal baik atau buruk, sedangkan karakter adalah tabiat seseorang yang langsung di-drive oleh otak. Dari sudut pandang bisa dikatakan bahwa tawaran istilah pendidikan karakter datang sebagai bentuk kritik dan kekecewaan terhadap praktik pendidikan moral selama ini. Itulah karenanya, terminologi yang ramai dibicarakan sekarang iini adalah pendidikan karakter (character education) bukan pendidikan moral (moral education). Walaupun secara substansial, keduanya tidak memiliki perbedaan yang prinsipil. Dalam kaitannya dengan pendidikan akhlak, terlihat bahwa pendidikan kakrakter mempunyai orientasi yang sama, yaitu pembentukan karakter. ${ }^{23}$ Pendidikan karakter adalah pendidikan untuk "membentuk" kepribadian seseorang melalui pendidikan budi pekerti, yang hasilnya terlihat dalam tindakan nyata seseorang, yaitu tingkah laku yang baik, jujur, bertanggung jawab, menghormati hak orang lain, kerja keras, dan sebagainya. ${ }^{24}$

Daniel Goleman yang terkenal dengan bukunya Multiple Intelligences, dan Emosional Intelligence, menyebutkan bahwa pendidikan karakter merupakan pendidikan nilai, yang mencakup sembilan nilai dasar yang saling terkait, yaitu:

${ }^{22}$ Zubaedi, Desain Pendidikan Karakter..., hlm. 2-3.

${ }^{23}$ Jamil Suprihatiningrum, Strategi Pembelajaran: Teori \& Aplikasi, (Jogj karta: A-Ruzz Media, 2016), hlm. 257-258.

${ }^{24}$ Bambang Q-Anees dan Adang Hambali, Pendidikan Karakter Berbasis Al-Qur'an, (Bandung: Simbiosa Rekatama Media, 2009), hlm. 99. 
a. Responsibility (tanggung jawab);

b. Respect (rasa hormat);

c. Fairness (keadilan);

d. Courage (keberanian);

e. Honesty (kejujuran);

f. Citizenship (rasa kebangsaan);

g. Self-discipline (disiplin diri);

h. Caring (peduli), dan

i. Perseverance (ketekunan)

Jika pendidikan nilai berhasil menginternalisasikan kesembilan nilai dasar tersebut dalam diri peserta didik, maka dalam pandangan Daniel Goleman akan terbentuk seorang pribadi yang berkarakter, pribadi yang berwatak. Lebih lanjut dia mengatakan bahwa pendidikan nilai harus dimulai di rumah, dikembangkan di lembaga pendidikan sekolah dan diterapkan secara nyata dalam masyarakat (termasuk masyarakat politik, industri, usaha, dan lain-lain). Dalam pandangannya pendidikan nilai atau karakter amat penting sebab menurut hasil penelitiannya, keberhasilan atau sukses hidup seseorang itu 80\% ditentukan oleh karakternya (kecerdasan emosional, kecerdasan sosial, dan kecerdasan spiritual) dan hanya 20\% ditentukan oleh kecerdasan intelektualnya. ${ }^{25}$

Berdasarkan penjelasan tersebu, dapat diinterpretasikan bahwa pendidikan karakter merupakan pemecahan permasalahan yang sangat brilian dalam menghadapi persoalan degradasi akhlak/ karakter peserta didik. pendidikan karakter tidak hanya sekedar memberikan penjelasan kepada peserta baik tentang perilaku yang baik dan buruk, namun lebih ke arah mengimplementasikan nilai dasar karakter dalam kehidupan sehari-hari dengan pembiasaan sehingga menjadi karakteristik diri.

${ }^{25}$ Sutarjo Adisusilo, J.R., Pembelajaran Nilai Karakter..., hlm. 80-81. 


\section{Pembentukan Karakter}

Menurut Morison, kepribadian adalah apa yang dicapai seseorang individu dengan menampilkan hasil-hasil kultural dan evolusi sosial. Sementara C. H. Judd menyatakan, bahwa kepribadian adalah hasil lengkap, serta merupakan hasil keseluruhan dari proses perkembangan yang telah dilalui individu. Dalam kajian psikologi kepribadian diungkapkan, bahwa ada dua aspek utama, yang membentuk kepribadian, yakni: a) temperamen; dan b) watak (karakter). Pembentukan karakter pada dasarnya adalah wujud dari upaya sadar yang dilakukan untuk mengubah sikap dan perilaku. Sebagai sikap batin, karakter atau watak termasuk unsur kepribadian yang dapat diubah. Menurut Prof. Mar'at, sikap dipandang sebagai seperangkat reaksi- reaksi afektif terhadap objek tertentu berdasarkan hasil penalaran, pemahaman, dan penghayatan individu. Sikap merupakan predisposisi untuk bertindak senang atau tidak senang terhadap objek tertentu yang mencakup komponen kognisi, afeksi dan konasi. Dengan demikian sikap merupakan interkasi dari komponenkomponen tersebut secara kompleks. Dengan demikian sikap terbentuk dari hasil belajar dan pengalaman seseorang. Jadi bukan faktor bawaan. Dorothy Law Notle menghubungkan pembentukan sikap melalui proses belajar. Dorothy Law Notle mencoba melukiskan proses dimaksud dalam sebuah puisi berjudul "Children Learn What They Live " Anak-anak belajar dari kehidupan mereka. ${ }^{26}$

Jika anak dibesarkan dengan celaan, ia belajar memaki, Jike anak dibesarkan dengan permusuban, ia belajar berkelahi, Jika anak dibesarkan dengan cemoohan, ia belajar rendah diri, Jika anak dibesarkan dengan binaan, ia belajar menyesali diri, Jika anak dibesarkan dengan toleransi, ia belajar menahan diri, Jika anak dibesarkan dengan dorongan, ia belajar percaya diri, Jika anak dibesarkan dengan pujian, ia belajar menghargai,

${ }^{26}$ Jalaluddin, "Pendidikan Karakter Berbasis Keluarga", Jurnal Ta'dib, Volume XVII, No. 01, Juni 2012, hlm. 42-43. 
Jike anak dibesarkan dengan sebaik-baik perlakuan, ia belajar keadilan,

Jika anak dibesarkan dengan rasa aman, ia belajar menarub kepercayaan,

Jika anak dibesarkan dengan dukungan, ia belajar menyenangi diri, Jika anak dibesarkan dengan kasih sayang dan persahabatan,

Ia belajar menemukan cinta dalam kehidupan.

Puisi gubahan Dorotby Law Notle ini menyibak sejumlah rahasia tentang

pendidikan anak. Pertama, anak akan belajar dari pengalaman yang ia peroleh dari lingkungan dan perlakuan yang diterimanya. Dari ramuan pengalaman dan perlakuan ini pula sikap dan perilaku anak- anak terbentuk. Kedua, pendidikan merupakan proses yang panjang dan berkesinambungan. Untuk membentuk anak menjadi sosok pribadi tertentu, para pendidik mesti merancang bentuk maupun strategi bimbingan yang diinginkan. Ketiga, pendidikan adalah juga merupakan proses pembiasaan. ${ }^{27} \mathrm{Hal}$ ini dapat diterapkan di lembaga pendidikan, teruma lembaga pendidikan Islam sehingga pembentukan karakter peserta didik dalam menginternalisasikan nilai-nilai AlQur'an menjadi lebih optimal.

Secara historis pendidikan karakter merupakan misi utama para nabi. Muhammad Rasulullah sedari awal tugasnya memiliki suatu pernyataan unik, bahwa dirinya diutus untuk menyempurnakan karakter (akhlak). Manifesto Muhammad Rasulullah ini mengindikasikan bahwa pembentukan karakter merupakan kebutuhan utama bagi tumbuhnya cara beragama yang dapat menciptakan peradaban. Pada sisi lain, juga menunjukkan bahwa masing-masing manusia telah memiliki karakter tertentu, namun perlu disempurnakan. Islam hadir sebagai jalan untuk menyempurnakan karakter. Al-Qur'an adalah buku ajar yang menghadapi peserta didik masyarakat Arab yang berkarakter

${ }^{27}$ Jalaluddin, "Pendidikan Karakter Berbasis Keluarga”..., h. 43. 


\section{Asri Karolina}

belum sempurna. Pembentukan karakter begitu memenuhi materi-materi awal Al-Qur'an, bahkan perintah ritual ibadah (shalat, zakat, puasa, dan haji) dikaitkan dengan tumbuhnya karakter yang baik. pada banyak ayat, ritual ibadah dianggap siasia (way) bila tidak muncul dalam wujud karakter yang baik dan memperbaiki (amal saleh). ${ }^{28}$

Berbicara masalah pembentukan karakter/akhlak sama dengan berbicara tentang tujuan pendidikan, karena banyak sekali dijumpai pendapat para ahli yang mengatakan bahwa tujuan pendidikan adalah pembentukan akhlak: ${ }^{29}$

1. Muhammad Athiyah al-Abrasyi mengatakan bahwa pendidikan budi pekerti dan akhlak adalah jiwa dan tujuan pendidikan Islam.

2. Ahmad D. Marimba berpendapat bahwa tujuan utama pendidikan Islam adalah identik dengan tujuan hidup setiap Muslim, yaitu untuk menjadi hamba Allah, yaitu hamba yang percaya dan menyerahkan diri kepada-Nya dengan memeluk agama Islam.

Dalam proses perkembangan dan pembentukannya, karakter seseorang dipengaruhi oleh dua faktor, yaitu faktor lingkungan (nurture) dan faktor bawaan (nature). Secara psikologis perilaku berkarakter merupakan perwujudan dari potensi Intelligence Quotient (IQ), Emotional Quotient (EQ), Spiritual Quotient (SQ), dan Adverse Quotient (AQ) yang dimiliki oleh seseorang. Konfigurasi karakter dalam konteks totalitas proses psikologis dan sosio-kultural pada akhirnya dapat dikelompokkan dalam empat kategori, yakni: (a) olah hati (spiritual and emotional development); (b) olah pikir (intellectual development), (c) olah raga dan kinestetik (physical and kinestetic development); dan (d) olah rasa dan karsa (affective and creativity development). Keempat proses psiko-sosial ini

${ }^{28}$ Bambang Q-Anees dan Adang Hambali, Pendidikan Karakter Berbasis Al-Qur'an..., hlm. 100-101.

${ }^{29}$ Abuddin Nata, Akblak Tasawnf, (Jakarta: Rajawali Pers, 2006), hlm. 155. 
secara holistik dan koheren saling terkait dan saling melengkapi dalam rangka pembentukan karakter dan perwujudan nilai-nilai luhur dalam diri seseorang. ${ }^{30}$

Ada tiga aliran yang sudah amat populer menjelaskan tentang faktor-faktor yang mempengaruhi pembentukan akhlak. Pertama, aliran Nativisme, kedua, aliran Empirisme, dan ketiga aliran Konvergensi. ${ }^{31}$

Menurut aliran nativisme bahwa faktor yang paling berpengaruh terhadap pembentukan diri seseorang adalah faktor pembawaan dari dalam yang bentuknya dapat berupa kecenderungan, bakat, akal, dan lain-lain. Jika seseorang sudah memiliki pembawaan atau kecenderungan kepada yang baik, maka dengan sendirinya orang tersebut menjadi baik. Aliran ini tampaknya begitu yakin terhadap potensi yang ada dalam diri manusia, dan hal ini kelihatannya erat kaitannya dengan pendapat aliran intuisisme dalam hal penentuan baik dan buruk sebagaimana telah diuraikan di atas. Aliran ini tampak kurang menghargai atau kurang memperhitungkan peranan pembinaan dan pendidikan.

Selanjutnya menurut aliran empirisme bahwa faktor yang paling berpengaruh terhadap pembentukan diri seseorang adalah faktor dari luar, yaitu lingkungan sosial, termasuk pembinaan dan pendidikan yang diberikan. Jika pendidikan dan pembinaan yang diberikan kepada anak itu baik, maka baiklah anak itu. Demikian jika sebaliknya. Aliran ini tampak lebih begitu percaya kepada peranan yang dilakukan oleh dunia pendidikan dan pengajaran.

Sedangkan aliran konvergensi berpendapat pembentukan akhlak dipengaruhi oleh faktor internal, yaitu pembawaan si anak, dan faktor dari luar yaitu pendidikan dan pembinaan yang dibuat seara khusus, atau melalui interaksi dalam lingkungan sosial. Fithrah dan kecenderungan ke arah yang baik ada dalam diri

${ }^{30}$ Agus Wibowo, Manajemen Pendidikan Karakter di Sekolah (Konsep dan Praktik Implementasi), (Yogyakarta: Pustaka Belajar, 2013), hlm. 11.

${ }^{31}$ Abuddin Nata, Akblak Tasawuf..., hlm. 165. 
manusia dibina secara intensif melalui berbagai metode. Aliran yang ketiga ini tampak sesuai dengan ajaran Islam.

\section{Rekonstruksi Pendidikan Islam Berbasis Pembentukan Karakter: dari Konsep Menuju Internalisasi Nilai-Nilai Al-Qur'an}

Membicarakan pembentukan karakter sebenarnya sejalan dengan tujuan pendidikan terutama pendidikan Islam. Namun penerapan pendidikan Islam masih dalam tataran konsep, belum pada internalisasi nilai-nilai Al-Qur'an yang sejatinya merupakan dasar pokok pendidikan Islam dan sumber pendidikan Islam. Dengan demikian, kita dapat merekonstruksi pendidikan Islam berbasis pembentukan karakter dengan konsep internalisasi nilainilai Al-Qur'an.

Batasan karakter berada dalam dua wilayah. Ia diyakini ada sebagai sifat fitri manusia, sementara pada sisi lain ia diyakini harus "dibentuk" melalui model pendidikan tertentu. Aristoteles meyakini bahwa individu tidak lahir dengan kemampuan untuk mengerti dan menerapkan standar-standar moral, dibutuhkan pelatihan yang berkesinambungan agar individu menampakan kebaikan moral. sementara Socrates meyakini bahwa ada bayi moral dalam diri manusia yang meminta untuk dilahirkan, tugas pendidikan adalah membantu melahirkannya. Hadis Rasulullah menegaskan bahwa tugas kenabian Muhammad Rasulullah adalah untuk menyempurnakan akhlak. Ini berarti telah ada benih akhlak pada masing-masing manusia, tinggal bagaimana lingkungan pendidikan dapat mengoptimalkan benih-benih tersebut. Sejalan dengan hadis lain yang menegaskan bahwa manusia dilahirkan dalam keadaan fitri, bergantung pada bagaimana lingkungannya yang akan membentuk kefitrian itu dalam warna tertentu yang khas. Merujuk pada teori-teori tersebut, pendidikan karakter berdiri di atas dua pijakan. Pertama, keyakinan bahwa pada diri manusia telah terdapat benih-benih karakter dan alat pertimbangan untuk menentukan kebaikan. Namun seperti sebuah benih, ia belum menjadi apa-apa, ia harus dibantu untuk ditumbuhkembangkan. 
Kedua, pendidikan berlangsung sebagai upaya pengenalan kembali sekaligus mengafirmasi apa yang sudah dikenal dalam aktualitas tertentu. Metode Aristoteles yang menekankan pada pengulangan dapat digunakan, namun setelah masing-masing peserta didik menyadari akan pentingnya apa yang diulang. Metode penyadaran dapat menggunakan teknik kebidanan Socrates, yaitu dengan cara membangkitkan kesadaran peserta didik akan pentingnya karakter yang akan dilatihkan. ${ }^{32}$

Ada 3 hal yang bisa dilakukan dalam merekontruksi pendidikan Islam berbasis pembentukan karakter dengan konsep internalisasi nilai-nilai Al-Qur'an yaitu: pertama, pendidik harus terlebih dahulu melakukan pengenalan pribadi dengan peserta didik, dengan kata lain mengenali perbedaan karakteristik dan kematangan peserta didik, sehingga terjalin komunikasi yang baik antara pendidik dan peserta didik. kedua, semua pihak yang terlibat di dalam lembaga pendidikan harus menampilkan diri sebagai suri tauladan bagi peserta didik. ketiga, menerapkan pendidikan karakter berbasis Al-Qur'an dengan 4 tahapan yaitu pengalaman pembelajaran, refleksi, aksi, dan evaluasi.

Prinsip metode "pembidanan" dan "afirmasi dan altuaklisasi" dijadikan metode dasar bagi seluruh kegiatan pendidikan karakter. Secara teknis, urutan pendidikan karakter berbasis Al-Qur'an dapat berlangsung dengan urutan sebagai berikut: ${ }^{33}$

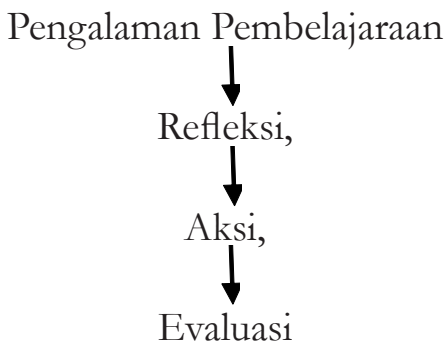

32 Bambang Q-Anees dan Adang Hambali, Pendidikan Karakter Berbasis Al-Qur'an..., hlm. 120.

33 Bambang Q-Anees dan Adang Hambali, Pendidikan Karakter Berbasis Al-Qur'an..., hlm. 122-127. 
Tahap Pertama: Pengalaman Pembelajaran atau Pengenalan.

Pengalaman adalah suatu kegiatan yang melibatkan dimensi kognitif dan afektif. Melalui pengalaman peserta didik mengalami suatu tantangan terhadap pengetahuan yang sudah dimilikinya dengan fakta, ide, dan masukan baru dari pendidik. Melalui pengalaman, konteks (pengetahuan asal, kebiasaan dasar, pengalaman sebelumnya) yang dibawa peserta didik dihadapkan pada suatu pengalaman baru, sesuatu yang memungkinkan untuk sepaham atau berkebalikan dengan konteks yang sebelumnya telah dimiliki oleh peserta didik. Pengalaman pembelajaran merupakan penerapan dari 2 dari metode $4 \mathrm{M}^{34}$, yaitu mengetahui dan mencintai.

Metode yang dapat dilakukan untuk membawa peserta didik pada pengalaman dapat berupa aktivitas bersama, problem solving, aktivitas mandiri, dan peer-group learning. Sebelum tahap pertama dilakukan, pengajar harus menentukan terlebih dahulu ayat atau surat apa yang menjadi sumber dan prinsip nilai (serta karakter) apa yang hendak diajarkan. Ini berarti pengajar harus memahami secara utuh ayat/surat Al-Qur'an serta maknanya dalam kaitan dengan prinsip nilai dan karakter.

Tahap Kedua: Refleksi

Refleksi adalah proses pencarian arti untuk pengalaman pembelajaran. Refleksi merupakan suatu proses (1) untuk mengedepankan perolehan makna dalam pengalaman manusiawi dengan pemahaman lebih baik mengenai kebenaran yang telah dipelajari; (2) untuk mengerti akan sumber perasaan dan reaksi yang dialami seseorang lewat apa yang dipelajari; (3) untuk

${ }^{34}$ Formula 4 M Ratna Megawangi yaitu mengetahui, mencintai, men inginkan, dan mengerjakan (knowing the good, loving the good, desiring the good, and acting the good) adalah urutan proses pengajaran yang bermula dari memberikan pengetahuan peserta didik tentang kebaikan, menggiring atau mengondisikan agar peserta didik mencintai kebaikan tersebut, kemudian membangkitkan peserta didik agar menginginkan karakter yang diajarkan, dan terakhir mengondisikan peserta didik agar mengerjakan kebaikan secara sukarela, simultan dan berkesinambungan. 
memperdalam pemahaman tentang implikasinya baik bagi dirinya sendiri maupun bagi orang lain; (4) untuk mendapat pengertian personal akan kejadian-kejadian dan ide-ide yang ada.

Pada tahap refleksi ini peserta didik dapat menghasilkan kesimpulan seperti prinsip-prinsip nilai yang telah dirancang oleh guru. Seperti: Setiap tindakan pasti dilakukan atas dasar apa atau atas dasar siapa, tindakan yang baik dilakukan atas dasar kasih sayang (prinsip bismillahirrahmanirrahim); atau kebaikan yang patut mendapat pujian didapatkan pada orang yang memelihara lingkungan, kasih sayang pada sesama, dan merencanakan masa depannya (pinsip ayat 1-3)

\section{Tahap Ketiga: Aksi atan Afirmasi}

Setelah peserta didik melakukan refleksi dan menemukan makna yang membangkitkan kecintaan dan keinginan untuk melakukan, peserta didik didorong untuk melakukan aksi tertentu.

Aksi adalah upaya untuk mengajari peseta didik dalam melakukan pilihan-pilihan dari berbagai sistem nilai yang ada. Aksi di sini berarti penentuan pilihan yang mengubah cara pandang lama ke cara pandang baru. Misalnya, peserta didik diminta untuk menyadari kebiasaan lamanya dan membandingkan dengan prinsip tindakan yang telah dihasilkan dalam refleksi; kemudian peserta didik didorong untuk "mengganti" atau "mengubah" tindakannya.

Pada tahap ini, sistem pembelajaran dapat menerapkan proyek riyadhah. Pertama, peserta didik bersepakat dengan pengajarnya untuk melakukan proyek riyadhah (pelatihan pembentukan kebiasaan baru), misalnya "mulai besok, saya akan bangun pagi dan langsung mengaji Al-Qur'an; kedua, pengajar dan peserta didik menentukan srandar penilaian apa yang akan ditetapkan bagi proyek tersebut dan berapa batas waktu yang hendak ditempuh; ketiga, pengajar menetapkan bahwa peserta didik harus menuliskan perkembangan pelaksanaan proyek 
tersebut dalam setiap harinya pada buku khusus (buku riyadhah, misalnya).

\section{Tahap Keempat: Evaluasi}

Setelah melewati batas waktu yang ditentukan, peserta didik dapat menyetorkan apa yang menjadi proyeknya. Peserta didik dan pengajar melakukan evaluasi secara bersama-sama: bagaimana pengalamannya, tingkat kesulitan, keberhasilan menghadapi tantangan, keberhasilan untuk konsisten, apa hasil positif yang didapatkan, dan seterusnya.

Evaluasi berarti student centered evaluation. Evaluasi dilakukan dalam konteks dan pengalaman peserta didik yang melakukan tindakan atau aksi. Jadi yang digunakan bukan sudut pandang pendidik. Pendidik adalah subjek yang menemani peserta didik untuk berkembang, yang berarti juga teman bagi peserta didik untuk evaluasi dilakukan dalam konteks dan pengalaman peserta didik yang melakukan tindakan atau aksi. Jadi yang digunakan bukan sudut pandang pendidik. Pendidik adalah subjek yang menemani peserta didik untuk berkembang, yang berarti juga teman bagi peserta didik untuk menilai perkembangan dirinya. Hasil yang ingin diraih dari evaluasi: peserta didik mampu mengerti dengan kesadarannya sendiri, terlebih tentang posisi dirinya terhadap tindakan yang dievaluasi.

\section{Simpulan}

Pendidikan Islam saat ini masih menghadapi berbagai masalah. Capaian hasil pendidikan masih belum memenuhi tujuan pendidikan Islam yang diharapkan. Pembelajaran di kelas juga belum mampu membentuk pribadi lulusan yang mencerminkan karakter muslim yang bernilai. Proses pendidikan Islam masih menitikberatkan dan memfokuskan pada capaian secara kognitif belum pada aspek afektif yang merupakan bekal kuat untuk hidup berdampingan dengan masyarakat dan dapat menjadi agent of change bagi lingkungan masyarakat yang sedang 
menghadapi kemerosotan karakter/akhlak. Maka perlu adanya rekonstruksi pendidikan Islam berbasis pembentukkan karakter dengan konsep internalisasi nilai-nilai Al-Qur'an yang seejatinya merupakan dasar pokok pendidikan Islam.

Pendidikan karakter merupakan pemecahan permasalahan yang sangat brilian dalam menghadapi persoalan degradasi akhlak/ karakter peserta didik. Pendidikan karakter tidak hanya sekedar memberikan penjelasan kepada peserta baik tentang perilaku yang baik dan buruk, namun lebih ke arah mengimplementasikan nilai dasar karakter dalam kehidupan sehari-hari dengan pembiasaan sehingga menjadi karakteristik diri.

Ada 3 hal yang bisa dilakukan dalam merekontruksi pendidikan Islam berbasis pembentukan karakter dengan konsep internalisasi nilai-nilai Al-Qur'an yaitu: pertama, pendidik harus terlebih dahulu melakukan pengenalan pribadi dengan peserta didik, dengan kata lain mengenali perbedaan karakteristik dan kematangan peserta didik, sehingga terjalin komunikasi yang baik antara pendidik dan peserta didik. Kedua, semua pihak yang terlibat di dalam lembaga pendidikan harus menampilkan diri sebagai suri tauladan bagi peserta didik. Ketiga, menerapkan pendidikan karakter berbasis Al-Qur'an dengan 4 tahapan yaitu pengalaman pembelajaran, refleksi, aksi, dan evaluasi. 


\section{Daftar Pustaka}

Arifin, H.M., Ilmu Pendidikan Islam: Tinjauan Teoretis dan Praktis Berdasarkan Pendekatan Interdisipliner, Edisi Revisi, Jakarta: Bumi Aksara, 2011.

Basri, Hasan, Filsafat Pendidikan Islam. Bandung: Pustaka Setia, 2009.

Dimyati, "Peran Guru sebagai Model dalam Pembelajaran Karakter dan Kebajikan Moral Melalui Pendidikan Jasmani”, dalam Cakrawala Pendidikan, (Yogyakarta, UNY, Mei 2010, Th. XXIX, Edisi Khusus Dies Natalis UNY).

Hawi, Akmal. Kapita Selekta Pendidikan Islam, Palembang: IAIN Raden Fatah Press, 2008.

Hermawansyah, "Pendidikan Karakter Berbasis Nilai-Nilai Islam", Jurnal Ilmiah "Kreatif" Jurnal Studi Pemikiran Pendidikan Agama Islam, Volume XII No. 1, Januari 2015.

J.R., Sutarjo Adisusilo, Pembelajaran Nilai Karakter: Konstruktivisme dan VCT sebagai Inovasi Pendekatan Pembelajaran Afektif, Jakarta: PT. Rajawali Pers, 2013.

Jalaluddin, "Pendidikan Karakter Berbasis Keluarga", Jurnal Ta’dib, Volume XVII, No. 01, Juni 2012.

dan Dian Andayani. Pendidikan Karakter Perspektif Islam, Bandung: PT. Remaja Rosdakarya, 2012.

Muthoifin dan Mutohharun Jinan, "Pendidikan Karakter Ki Hadjar Dewantara: Studi Kritis Pemikiran Karakter dan Budi Pekerti dalam Tinjauan Islam", Jurnal Profetika, Jurnal Studi Islam, Volume 16, No. 2, Desember 2015.

Nata, Abuddin, Akblak Tasawuf, Jakarta: Rajawali Pers, 2006.

Q-Anees, Bambang dan Adang Hambali. Pendidikan Karakter Berbasis Al-Qur'an, Bandung: Simbiosa Rekatama Media, 2009. 
Rahman, Amri \& Dulsukmi Kasim, "Pendidikan Karakter Berbasis Al-Qur'an; Upaya Menciptakan Bangsa yang Berkarakter", Jurnal Al-Ulum IAIN Sultan Amai Gorontalo, Volume 14 Nomor 1, Juni 2014.

Rakhmawati, "Pendidikan Karakter dalam Perspektif Islam", Jurnal Al-Ulum (Jurnal Studi-Studi Islam) IAIN Gorontalo, Volume 13 Nomor 1, Juni 2013.

Suprihatiningrum, Jamil, Strategi Pembelajaran: Teori \& Aplikasi, Jogjakarta: A-Ruzz Media, 2016.

Uhbiyati, Nur, Dasar-Dasar Ilmu Pendidikan Islam, Semarang: Pustaka Rizki Putra, 2013.

Wibowo, Agus, Manajemen Pendidikan Karakter di Sekolah (Konsep dan Praktik Implementasi), Yogyakarta: Pustaka Belajar, 2013.

Zubaedi, Desain Pendidikan Karakter: Konsepsi dan Aplikasinya dalam Lembaga Pendidikan, Jakarta: Kencana Prenada Media Group, 2011.

Zuhdi, Darmiyati, Pendidikan Karakter, Yogyakarta: UNY, 2009. 
Asri Karolina 